\title{
La política exterior chileno-boliviana en la década de 1950 mirada desde la región de Tarapacá. Una aproximación desde el diálogo entre las teorías de las percepciones y el realismo neoclásico ${ }^{1}$
}

\author{
Cristián Ovando Santana \\ Instituto de Estudios Internacionales de la Universidad Arturo Prat, Iquique, Chile \\ Email: covando@unap.cl \\ Sergio González Miranda \\ Instituto de Estudios Internacionales de la Universidad Arturo Prat, Iquique, Chile \\ Email: pampino50@gmail.com
}

Resumen: El objetivo de este artículo es revelar algunas claves de la política exterior chileno -boliviana de la década de 1950 vista desde la región de Tarapacá. Para ello, indagamos en una serie de variables que determinan las orientaciones de las respectivas políticas exteriores de ambos países, desde las teorías de las percepciones y el realismo neoclásico: intereses, capacidades, imágenes e ideologías. Desde estos argumentos, y rastreando notas de prensa de esa década, analizamos el comportamiento de la diplomacia y paradiplomacia chilena y boliviana en el marco del diálogo teórico mencionado.

Palabras clave: Política exterior, teoría de las percepciones, realismo neoclásico, diplomacia.

\section{Chilean-Bolivian foreign policy in the 50's, viewed from the region of Tarapacá. An approach from the dialogue between theories of perceptions and neoclassic realism}

Abstract: This article aims to reveal some keys of the Chilean-Bolivian foreign policy in the 50's, seen from the region of Tarapacá. For that we made inquiries into a series of factors that determine the directions of the foreign policies in both countries, from the theories of perceptions and the neoclassic realism: interests, capacities, images and ideologies. From these arguments, and tracing press release of the decade, we examined the behaviour of Chilean and Bolivian diplomacy and paradiplomacy under the mentioned theoretical dialogue. diplomacy.

Key words: Foreign policy, theory of perceptions, neoclassic realism, 


\section{Chile-Bolívia política externa na década de 50 , vista a partir da região de Tarapacá. Uma abordagem a partir do diálogo entre as teorias da percepção e realismo neoclássico}

Resumo: Este artigo tem como objetivo revelar algumas chaves da política estrangeira chilena - boliviana na década de 50, visto a partir da região de Tarapacá. Para eso fizemos investigações sobre uma série de fatores que determinam os rumos das políticas externas dos dois países, a partir das teorias da percepção e do realismo neoclássico: interesses, capacidades, imagens e ideologias. A partir desses argumentos, e do rastreamento das notícias de imprensa da década, analisamos o comportamento da diplomacia chilena e boliviana e paradiplomacia no âmbito do diálogo teórico mencionado.

Palavras-chave: política externa, a teoria da percepção, neoclássico realismo diplomacia.

$$
* * *
$$

\section{Introducción}

En el debate teórico presente en la región acerca de la posibilidad de establecer modelos de análisis de política exterior, el enfoque de las percepciones -imágenes e ideologías- (Berna-Meza,1999,2005; Frigeiro,2002; Herrero de Castro,2006) es considerado una aproximación a tener en cuenta para abordar las relaciones bilaterales de los países sudamericanos, sobre todo las relaciones delicadas ( Muñoz, 1986) o en momentos de crisis (Jervis,1976). En este marco, si bien podría ser discutible que las relaciones bilaterales entre Bolivia y Chile puedan definirse como delicadas o en crisis, pues a pesar de la ausencia de relaciones diplomáticas y de recurrentes tensiones en el plano del discurso político, han demostrado una notable estabilidad. Sin embargo, es innegable que existe una tensión no sólo diplomática entre ambos estados y que tiene su impacto a escala de ambas sociedades. Nos centraremos en la década de 1950, que se ha definido como aquella de mayor acercamiento entre ambos Estado-naciones, pero, por lo mismo, las percepciones y expectativas alcanzaron su punto máximo y frente al fracaso diplomático se llegó igualmente a un momento de alta tensión cuando se iniciaba la década siguiente de 1960.

Esta corriente, si bien su origen no es propiamente latinoamericano, se considera una entrada adecuada, a partir de la década de 1970 del siglo pasado, en el marco de los nuevos enfoques (Rusell, 1992). En efecto, Roberto Rusell señala que los enfoques sobre ideologías, imágenes y percepciones de autores como Jervis o George, aunque no son tan extendidos, comienzan a tomarse en cuenta en los estudios de política exterior, posibilitando nuevas entradas en el debate latinoamericano que surgirían a partir de "la hipótesis según la cual (...) la visión del otro - sustentadas a menudo en imágenes erróneas o preconceptos-, habrían influido en la formula- 
ción de las respectivas políticas externas, en particular sobre las relaciones bilaterales limítrofes” (Bernal-Meza, 2005:278).

Dentro de las principales premisas de la teoría de la percepción, se señala que al analizar la política exterior de los países se debe tener en cuenta tanto el contexto internacional como el doméstico, por ello no se debe homogenizar la conducta de los estados en base a las constricciones estructurales, como señala el realismo. Plantea se debe buscar la singularidad a partir de cómo se percibe el Estado en el concierto internacional y cómo percibe a sus pares, sobre todo con los que posee grados considerables de interdependencia. Como es el caso de Bolivia y Chile, donde las relaciones transfronterizas, a pesar de los conflictos diplomáticos, son crecientes y seguirán esa tendencia por la mutua dependencia que tienen algunas regiones contiguas de ambos países, donde fenómenos como la migración y las organizaciones indígenas de frontera seguirán persistiendo bajo cualquier escenario. Y, por el contrario, a escala nacional, los discursos políticos de los mandatarios y/o cancilleres, suelen generar climas de hostilidad o amistad que suelen ser volátiles, según sea el impacto que tengan en la prensa.

En este marco, los tomadores de decisiones en política exterior, en base a sus creencias y valores, actúan siguiendo sus mapas cognitivos que representan el mundo en un instante de tiempo. Se centran en cómo perciben al resto en tanto actores inscritos en una determinada posición en el sistema internacional. Probablemente este ha sido uno de las principales explicaciones de las dificultades para entenderse entre las cancillerías de Bolivia y Chile, donde esta última ha privilegiado durante los Gobiernos de la Concertación de Partidos por la Democracia un enfoque economicista de las relaciones internacionales ${ }^{2}$. En cambio, la cancillería boliviana ha continuado privilegiando el enfoque político. Recordemos el fracaso del TLC entre ambos países. Bolivia y Chile, a pesar de los trece puntos sin exclusión, no tienen agendas similares en política exterior. Este fenómeno Kehoane lo denomina genéricamente la persistencia de un "sistema de relacionamientos dispares". Se entiende que este sistema es uno en que prevalecen roles distintos, de crucial importancia, respecto a sus posiciones y estrategias de inserción internacional, (2002:15) repercutiendo en las acciones y respuestas hacia el escenario subregional y bilateral. Estos roles distintos se aprecian cuando se coteja la realidad objetiva y las percepciones subjetivas que tiene un actor hacia otro y hacia el contexto internacional en que se desenvuelven. Esta disonancia; como se argumentará más adelante, contribuye al deterioro o inercia de las relaciones entre los países.

Esta posición en el sistema internacional también refleja el mundo nuestro, el que creemos es el legítimo; aunque no se ajuste a la veracidad. De hecho, las distorsiones son sumamente probables en las relaciones internacionales. (Downs y Stea: 1977.Citado por Schumacher, 2002:81,82), pues es allí donde las decisiones, con unos márgenes determinados de maniobra dentro de las estructuras ineludibles, ocupan un lugar sobresaliente (Schumacher, 2002). 
A partir de estos supuestos, este trabajo se pregunta: ¿Cuáles son las percepciones mutuas que han poseído los estados de Chile y Bolivia en su acontecer internacional, sobre todo a lo largo de la década de 1950? ¿Qué procesos de cambio de percepciones podemos observar a lo largo de ciertos hitos en su compleja relación? ¿Cómo han influido estas percepciones en la posición que ostentan ambos en el sistema internacional y en el contenido de sus relaciones?

Con todo, el objetivo de este artículo es revelar algunas claves de la política exterior chileno -boliviana de la década de 1950. Para ello, indagamos en una serie de variables que determinan las orientaciones de las respectivas políticas exteriores, propias de los enfoques teóricos de las Relaciones Internacionales teoría de las percepciones y el realismo neoclásico: intereses, capacidades, imágenes e ideologías. Desde estos argumentos, y rastreando notas de prensa de la época, analizamos la denominada época dorada de las relaciones entre estos dos países.

Cabría preguntarse, ¿por qué hemos escogido este enfoque para analizar las relaciones entre Bolivia y Chile, más allá de lo estrictamente teórico?, ha sido porque desde el término la Guerra del Pacífico han sido precisamente las percepciones “del otro” las que han prevalecido en los discursos políticos y pedagógicos e, incluso, en la construcción de la historia comparada. Precisamente, en la década de 1950, aparentemente, las percepciones comenzaron a aproximarse hacia un campo semántico compartido, en base a la gestión mediadora de EE.UU., al clima de posguerra marcado por una mayor integración y la coincidencia en cuanto al emprendimiento de ambos de procesos domésticos desarrollistas, que conllevaron obras concretas como acueducto de Sica Sica, entre otros.

Brevemente, el itinerario del trabajo es el siguiente: primero, describimos los principales aspectos de los enfoques teóricos propuestos y su desarrollo en el debate latinoamericano. A continuación, teniendo en cuenta los aportes teóricos, describimos algunos hitos del desarrollo histórico de las relaciones chileno bolivianas. Finalmente, analizamos algunas notas de prensa que dan cuenta de la denominada época dorada de las relaciones entre estos dos países.

\section{Aspectos Teóricos}

Dentro de los debates ontológicos de las Relaciones Internacionales de a mediados del siglo pasado, se discute si es una opción plausible que 1os individuos que han de tomar decisiones lo hagan racionalmente, y si una política internacional que apueste por el comportamiento racional continuado será sostenible (Deutsch, 1990; Salomón, 2002).

La crítica apunta al clásico axioma realista que plantea que los hombres de estado piensan y actúan siguiendo un interés nacional entendido como poder, tratándose de un interés dado y casi invariable. La 
política exterior se explica en este sentido por intereses estatales, objetivos, determinados por constricciones estructurales externas (Morgenthau, 1986) y no por las decisiones subjetivas de los que tienen que tomarlas, que podrían dotar de nuevos contenidos y significados dicho interés (intereses comunes y compartidos entre dos comunidades humanas), majaderamente denominado interés nacional ${ }^{3}$. Aunque aproximaciones realistas, como es el caso de la teoría de la disuasión y la del espiral "han colocado la cuestión de las percepciones en un papel central, pero siguen considerando la toma de decisiones como un proceso racional. (Rodao, 2005:215).

En cambio, para las aproximaciones sobre la percepción, la acción estatal se considera la acción tomada a partir de tomadores de decisiones diplomáticos-, nutridos de una capacidad analítica que los faculta a la recreación de la realidad desde la manera como ellos lo ven( Jervis,1970; de Castro,2006). Precisamente, el papel muy influyente de algunos personajes en la diplomacia boliviana y chilena, ha sido clave para distender o tensionar las relaciones bilaterales; como fue el Tratado de 1904 o el surgimiento de conflictos, como las crisis de 1962 y 1978.

En definitiva, las actuaciones en la política exterior se determinan sobre todo por las capacidades materiales, las informaciones y 1os motivos de 1 os actores. Aun más, en cuanto a los cambios de las decisiones en política exterior, esta corriente señala que son las imágenes las primeras en cambiar, seguidas por las decisiones políticas (Rodao, 2005), aunque cambien las condiciones materiales, como es el caso de del aumento o disminución de las cuotas de poder que se traduzcan en posiciones más o menos privilegiadas en dichas relaciones. Con ello, los factores externos tienen solo relevancia si 1os actores 1os introducen en el proceso de la decisión mediante su percepción.

En este contexto, surge una mirada revisionista desde el realismo que complementa la mirada materialista con las subjetividades propias de las teorías de las percepciones. Así, el realismo neoclásico se propone explicar la conducta de estados individuales que son esencialmente el producto de cómo el Estado interpreta su posición en el sistema internacional y actúa de acuerdo a las capacidades con las que cuenta (Merke, 17).

Otras aproximaciones complementarias acerca de la diplomacia, ponen relevancia en la variable cultural desde un punto de vista de la alteridad. Así, la relevancia de la cultura en las Relaciones Internacionales, radica en reflejar una identidad, las ideas y una determinada visión del mundo o de una sociedad, Estado, nación compartida por distintas unidades políticas a partir de sus vínculos diplomáticos.

Para Der Derian, desde la alteridad, la diplomacia es fundamentalmente una forma de diálogo con el otro, que posibilita el acercamiento de culturas en tanto vehículo para el contacto entre comunidades humanas organizadas. Existiendo, siempre en clave dialógica, la posibilidad de tender 
puentes a través de los cuales se va produciendo una comunicación que enriquece, que nos acercan al otro hasta el extremo en que las identidades se van difuminando (Der Derian, 1998:30).

Para Manuel montubio, la relación entre diplomacia y el nuevo discurso sobre el "otro", determina que las características esenciales de toda acción diplomática sean: descubrimiento, exploración, invención y relación con el "otro", todas ellas nos encaminan precisamente hacia el discurso del “otro”. (2004). Siguiendo esta línea, James Der Derian (...), se pronuncia al definir la diplomacia como el arte de la mediación entre extraños grupos, individuos o sujetos, es decir entre “otros”. (1987; 1998). No obstante, el mismo autor explicita las dificultades de esta posibilidad en la medida que la identidad del Estado también sufre de las aprehensiones de inseguridad y la larga historia de enajenaciones que ha creado identidades profundas y una creencia racionalista que el Estado busca mantener a raya las contingencias de la vida (Der Derian, 1998:35) En definitiva, estas contingencias inducen al Estado a una negación de la identidad extraterritorial.

Es justamente este proceso de enajenación el que determina la necesidad de una diplomacia superadora. Para Montobio, "la diplomacia existe y es necesaria precisamente porque existe este enfoque de alteridad en las relaciones entre estados y pueblos. Y aunque no se diseñe para superar esa alteridad, creo que está en el origen de esa superación siempre deseable" (2004) Por ello, la década de 1950, la de mayor acercamiento entre ambos estado-naciones, podría constituirse en una instancia de diplomacia superadora.

\section{Realismo neoclásico: variables intervinientes en torno a las percepciones.}

Dentro de las corrientes realistas surge una tercera generación posterior al realismo estructural (Waltz, 1979), que se aproxima a la teoría de las percepciones. Se trata del realismo neoclásico. (Zakaria, 2000; Rose, 1998). Esta corriente pretende explicar la acción de los estados a partir de una política exterior singular y no sólo a través de variables externas como son las presiones sistemáticas proporcionadas por la anarquía (Lawson, 2006). En este sentido, supera las generalizaciones propias de las familias realistas, explicando a partir de patrones individuales de política exterior, resultados distintos, aun cuando se ubiquen de manera similar en el entramado internacional (Merke, 2006).

Estas aproximaciones pretenden complementar los postulados básicos del realismo estructural, pues señalan que "sin incorporar ámbitos como la ideología, la percepción, las relaciones internas entre el Estado y la sociedad, el realismo estructural fracasa en su intento de explicar por qué los estados mantienen el equilibrio o se suben al carro del triunfador, se ocultan o superan sus limitaciones, actúan punitivamente hacia otros (Lawson, 2006:5). 
Como toda aproximación de las Relaciones Internacionales más contemporáneas, en cuanto a su debate ontológico y diálogo de paradigmas, complementa a los factores materiales elementos ideacionales ${ }^{4}$, toda vez que se propone explicar la conducta de estados individuales tanto producto de cómo el Estado interpreta su posición en el sistema internacional como de acuerdo a las capacidades con las que cuenta. (Merke, 2006). Argumenta que el impacto de las capacidades materiales de poder en la política exterior (control de recursos y espacios, e influencias externas hacia éstos) es indirecto y complejo, porque las presiones sistémicas deben traducirse a través de variables intervinientes al nivel de la unidad. (Rose 1998: 146). Variables intervinientes ubicadas en las unidades domésticas (a través de tomadores de decisiones, y sus propias percepciones), que configuran la política exterior particular.

Por otro lado, quienes toman decisiones, no siempre pueden ir en la dirección de su elección, en la medida que media la variable "relación entre la elite política y la sociedad en general”, limitando la acción externa.

En suma, para el realismo neoclásico, la variable independiente sigue siendo la distribución de poder en el sistema internacional, pero, agregan un conjunto de variables intervinientes, domésticas, en torno a las percepciones: ideologías, complementariedad de las elites, convergencia con los grupos estratégicos de las sociedad, etc. Sin embargo, vemos que en el caso de Bolivia y Chile "las variables intervinientes" tienen un papel más decisivo que las "estructurales", desde la época de la "política boliviana" que, si bien, pudo tener mucho de pragmática, se sustentó en una "percepción del otro".

De la presencia de estas variables intervinientes - el conjunto de percepciones de los tomadores de decisiones, a través de las cuales se filtran presiones sistémicas- se deduce un elemento clave para el investigador: la imposibilidad de la existencia de un actor racional ${ }^{5}$. Plantea una crítica al enfoque Racional Choice aplicado a las Relaciones Internacionales. Su argumentación apunta desestimar el supuesto de un actor racional, como elemento dado, que funcione como una correa de transmisión entre los atributos del sistema y la acción de los estados (Merke, 2006).

Con ello, a los cambios en la distribución de capacidades y su incidencia en cambios de las conductas de los estados, media cómo los actores interpretan o perciben el aumento o declive de sus capacidades relativas.

Una segunda variable interviniente de este enfoque apunta a la relación del Estado con la sociedad y su incidencia en la toma de decisiones en materia de política exterior. Se pregunta qué posibilidad tienen los tomadores de decisiones de acceder a los recursos del Estado (fundamentalmente, aunque no exclusivamente, control de las actividades económicas y sociales), lo que supone que el Gobierno ve fortalecida su habilidad para obtener recursos desde la sociedad y adjudicarlos en orientación a sus preferencias $^{6}$ (Merke, 2006). En suma, se preocupa del papel de las elites dirigen- 
tes y el nivel de autonomía que disponen frente a las presiones y demandas de la sociedad. (Tokatlian y Rusell, 2001). Nos referimos a cómo la variable régimen político ${ }^{7}$ afecta a la política exterior (Lasagna2005; Nohlem y Fernández, 1991).

De este modo, los estadistas deben afrontar las restricciones que les impone la estructura del Estado.

Finalmente, en cuanto al nivel de análisis, se trata de un realismo que busca la combinación del nivel sistémico con el nivel de la unidad. Sigue la propuesta generalizada en el debate acerca del nivel de análisis de las relaciones internacionales que señala la combinación entre los factores más sistémicos y los más individualizados, como son la política exterior y los subsistemas internacionales. En efecto, “el nivel general o sistémico de las Relaciones Internacionales, es producto de la combinación de políticas exteriores de los estados y otros actores, pero a la vez configura el marco de referencia y condicionamiento de las mismas. Entre ambos niveles hay una continua e intensa interacción e intercambio de mensajes explícitos e implícitos” (Arnoletto, 2007:285).Así, la teoría de las interdependencias ("Linkage Theory”), hace hincapié en el "continuum” que va desde el individuo hasta el sistema internacional global. Esta aproximación enfatiza en que "Las interacciones entre niveles son cada vez más complejas y dinámicas; las fronteras entre ellos son cada vez menos definidas. (Arnoletto, 2007:286).

\section{La teoría de las percepciones y su desarrollo en el debate latinoamericano}

Heraldo Muñoz (1986) en su modelo de análisis de la política exterior chilena para el Gobierno militar, propuso variables de análisis clave, destacamos dentro de ellas el proyecto dominante de desarrollo, que entrelaza lo doméstico con lo internacional y el estilo de la diplomacia desde la cual se desprende cómo factores y elementos subjetivos -valores y perspectivas ideológicas de los encargados de implementarla, la tradición diplomática del país y las normas no escritas del comportamiento internacional- se entrelazan y son impulsadas por los responsables de la política exterior (Muñoz, 1986;13, 14). En la misma perspectiva metodológica, Luciano Tomassini (1987) propone algunos factores claves que orientan las políticas exteriores, dentro de ellos, se aprecian desperdigadamente elementos que aluden al modelo de percepciones y al realismo neoclásico. Destaca la relación entre la política exterior, la sociedad y la historia , es decir con las estructura social , la cultura política y el régimen de gobierno heredados del pasado histórico , y lo que es más importante , una visión acerca del futuro (Tomassini,1987:126). A su vez, dentro de los elementos que considera para definir y diferenciar las políticas exteriores de los países, la percepción juega un rol relevante. Así, en cuanto a la variable agenda internacional, establece en primer lugar la identificación de los temas que la integran , dando identidad a problemas y oportunidades (es decir, la definición de los problemas y oportunidades sería un proceso endógeno a 
las interrelaciones de los actores comprometidos con la política); otro elemento que destaca y que se desprende de la misma variable son los criterios que operan a la hora de determinar las preferencias dentro de la agenda, para lo que establece algunas dimensiones clave: la percepción de los actores diseñadores de la política y la percepción de otros actores son las dimensiones que orientan la definición precisa de los temas e intereses del diseño de las políticas exteriores (Tomassini, 1987:127).

Con todo, el riesgo (y la importancia) de la percepción del otro en la política exterior vecinal entre Chile y Bolivia, es que puede transformarse en habitus (Bourdieu); es decir, toma forma en una sólida concepción de mundo y estructura del conflicto que termina naturalizándose, dificultándose posibilidades de cambio hacia relaciones más cooperativas orientadas por un campo semántico compartido.

Bernal-Meza (2005:257), profundizando los modelos de Muñoz y Tomassini, plantea previamente que ellos implícitamente condicionaban la política exterior, expresando sus tendencias y percepciones, a partir de la concepción ideológica y el marco de percepciones teóricopolíticas que subyacen a toda política. A partir de esta constatación, se propone profundizar en el modelo agregando variables de análisis tales como: proyecto interno dominante; interpretación sobre el sistema internacional; tendencia teóricas, políticas e ideológicas de la política exterior y principales áreas de articulación externa: intereses y jerarquías de los mismos en la agenda internacional. (Bernal- Meza, 2005:258).Su objetivo consistía en que a través de su perfeccionamiento se podría captar con mayor nitidez la cosmovisión desde la cual los hacedores de la política respondían a las variables externas e identificaban las influencias de ideas que mantenían su presencia en la formulación de la política exterior (BernalMeza, 2005: 257).

\title{
Política exterior de Chile y Bolivia en la década de 1950, época dorada de las relaciones chileno bolivianas
}

\author{
La evolución histórica y política-psicológica \\ de la relación entre Chile y Bolivia
}

Para adentrarnos en las percepciones que tiene una sociedad sobre los países vecinos, proyectándolas hacia la política exterior, debemos considerar las distintas matrices que fue construyendo la primera a lo largo de la historia. Esto lleva a precisar los distintos momentos de las relaciones bilaterales con los vecinos, pero también a ubicar el orden histórico en que se procesaron y también los sectores políticos y económicos dominantes que actuaron como constructores en el forjamiento de las imágenes (Bizzozero, 2009:7). Así, el paso de una matriz oligárquica a una clásica en America Latina (Garretón, 2002), junto con la ascensión de una diplomacia pragmática pero comprometida con el desarrollismo latinoamericano, como 
es el caso de chile (Witker, 2000; Devés, 2003), supuso un hecho relevante del escenario regional del Cono Sur: el cambio de percepción que los países han tenido hacia sus vecinos. Específicamente, lo relevante es que las naciones de ambos países, y sus autoridades políticas coincidieron en la mirada: la primera vio en el interior de continente grandes oportunidades económicas, posiblemente sobre la base de su memoria histórica; y la segunda, vio en el océano Pacífico su apertura al mundo, al mercado internacional para sus productos mineros y agropecuarios. Esa coincidencia de miradas también se expresó en imágenes coincidentes, donde las expectativas eran crecientes en la medida que las autoridades respondían a sus demandas y el clima diplomático era favorable.

Volviendo a las etapas previas a este giro, concretamente se trata del país con el que se libró una guerra de efectos duraderos, que de cuando en cuando se activan ya entrado el nuevo siglo. La pérdida de cualidad marítima para Bolivia, la anexión de la región de Antofagasta para Chile, el litigio por las aguas del río Silala, dentro de otros hitos, han marcado un siglo de relaciones conflictivas.

Ha sido un largo proceso, que comenzó en la posguerra del pacífico, continuó a lo largo del siglo XIX, se prolongó con altos y bajos en la entrada al nuevo siglo y se recrudeció como consecuencia de la influencia de los respectivos centro políticos, quienes comienzan a percibirse de manera negativa a parir de la década de 1960 del siglo XX. Su fundamento se encuentra en las respuestas (percepciones negativas por un sector de la elite) al proyecto modernizador emprendido en el continente, principalmente de corte nacionalista en el marco de la Guerra Fría. En efecto, para Pope Atkins, "los jefes latinoamericanos formulan políticas desde un punto de vista de intereses nacionales basados en teorías de seguridad nacional”. A lo que agrega "el pensamiento latinoamericano se concentra en los desafíos internos a la unidad nacional, con las percepciones externas limitadas a fronteras contiguas y controversias territoriales" (Atkins, 1991:471). Efectivamente, con el propósito de alcanzar la unidad nacional, escogieron el camino de hacerlo a través de la identidad por oposición, es decir, unirse en torno a un conflicto con el vecino, sea real o imaginado. Fue el caso de Bolivia con Chile y con Paraguay.

Esta mirada coincide con un estilo diplomático tradicionalistaintegrista (Wilhelmy, 1979) o pretoriano ideológico, “donde las Fuerzas Armadas le imprimen a la política exterior una visión anticomunista del mundo, un estilo ideologizado que privilegió la confrontación abierta por sobre la negociación inspirada en la Doctrina de la Seguridad Nacional” (Muñoz, 1986: 362-363). Mirada que se consolida en la década de 1980.

En este derrotero, Bolivia se consideró, al igual que sus vecinos más próximos, una amenaza para la seguridad de Chile, reeditando o dando cuenta de patrones culturales de larga duración, que se engarzan con el marco de la compleja historia de la estructuración fronteriza de todos los estados sudamericanos (Fernandois, 2005). 
Estos vínculos complejos se nutren de aproximaciones de política exterior de acuerdo a planteamientos teóricos vigentes para la época. Así encontramos en el contexto político-ideológico de Chile, la aceptación de algunas estrategias y percepciones del escenario internacional. Dentro de las que destacamos:

A) La percepción de la búsqueda de un equilibrio militar, regional, como elemento de las relaciones vecinales, en la medida que se concebía como clave para la defensa ante la amenaza vecinal(Fernandois y León, 2005).El equilibrio de poder siempre ha estado presente en la política exterior latinoamericana, (Burr,1965.Citado por Lacoste,2005:32) en vista a un escenario regional multipolar, la falta de sistemas hegemónicos y la presencia de constantes desajustes, que orientaban las políticas a nuevos ajustes de poder. Sin embargo, en la década de 1950 hubo coincidencias clave, como fue la importancia de los EEUU en el acercamiento entre Chile y Bolivia, junto con la promoción de estrategias anticomunistas por parte de la potencia hacia ambos países.

B) Para el caso de la historia de la estructuración fronteriza de todos los estados Sudamericanos, se dio un proceso a mediados del siglo XIX que definió el contenido de las políticas exteriores de la región: “...la imagen de que en la historia de la estructuración fronteriza del país éste habría sido amputado por un vecino agresivo y expansionista”. (Fernandois y León, 2005:96) Para el mismo autor, "cuando en la segunda mitad del siglo XX eclosionaron los problemas limítrofes como la cuestión central en las en las relaciones bilaterales, se había formado una imagen del vecino ya anclada en una conciencia historiográfica (Fernandois y León, 2005:96)

\section{Ideas y tendencias en torno a la política exterior chilena y a su estilo diplomático en la segunda mitad del siglo $\mathrm{XX}$}

Las señas de identidad de larga data de la política exterior chilena giran en torno a: la estabilidad institucional dada por su aislamiento geográfico, su centralismo y el presidencialismo como elementos clave de su régimen político; la importancia atribuida al factor territorial y la búsqueda del equilibrio de poder a nivel regional en vista a un escenario regional multipolar y la falta de sistemas hegemónicos, como ya señalamos; el estilo civil-pragmático de la diplomacia y su tradición legalista, (Colacrai y Lorenzzini,2005).

Otra entrada para analizar las ideas que orientan las respectivas políticas exteriores, surge de profundizar en el régimen político. En cuanto a la ideología que está en la base de un régimen y, por ende, en sus principales líderes, refleja las creencias básicas del grupo acerca de los asuntos mundiales y cómo ellos se relacionan con los intereses externos e internos del Estado. Lo importante es que la elite guía en torno a ella la naturaleza de la reacción del Estado ante estímulos internacionales; lo que se refleja en el estilo diplomático que adopta un régimen. (Lasagna, 1996).Wilhelmy 
complementa lo señalado al plantear que los estilos diplomáticos se explican a partir de "aquellos elementos de mayor gravitación en la cultura política de los actores más importantes...” (Wilhelmy, 1979: 305-306).

Este autor, distingue tres tipos de subculturas dentro de la cultura dominante de la política internacional de Chile. Una dominante moderada (1946-1970); una disidente de tipo revolucionario (1970-1973) y una tercera, tradicionalista-integrista (1973-1989) (Wilhelmy, 1979). La primera nos interesa. Caracterizó el periodo que estudiamos y, además un dato no menor, persisten sus rasgos actualmente. Sus características son: "la realización de un diagnóstico positivo del estatus y rol internacional de Chile, la valoración de la democracia, actitud internacionalista, orientación occidentalista y apoyo al status quo internacional cuyo corolario es la actitud legalista en lo relativo a la estructura del sistema internacional. (Wilhelmy, 1979). A lo que se agrega el reconocimiento practico de las realidades de poder mundial y preponderancia de los diplomáticos de carrera en el manejo de la política exterior (Muñoz, 1986).

Es destacable que el predominio de la subcultura dominante moderada, puede ser considerada como una fuerza profunda de larga trayectoria, (Colacrai y Lorenzzini, 2005) que no desapareció con el interludio de la dictadura.

Por otra parte, el factor territorial así como la cuestión de los límites, en la medida que el control estatal de recursos económicos y sociales requería del control de estos factores, estuvo condicionada por la cosmovisión de los actores involucrados. En efecto, aunque discutible, ¿realidad o mito?- la política chilena hacia Bolivia, históricamente, es una política de estado que cuenta con el apoyo de las principales fuerzas políticas.

La relevancia de los factores materiales en la relación chileno-boliviana, ha sido gravitante, ha incidido en las mentalidades de ambas sociedades y dirigencias políticas, limitando las relaciones entre ambos países. Aunque a lo largo del siglo XX, especialmente en la segunda mitad, en la denominada "segunda fase de las relaciones chileno bolivianas", marcadas por los avances experimentados en la búsqueda de soluciones, en el intercambio bilateral, principalmente el libre tránsito, se aprecia un mayor intercambio diplomático.

\section{Ideas y tendencias históricas de la política exterior boliviana}

Uno de los rasgos fundamentales en el ámbito interno que ha condicionado la política exterior boliviana han sido sus reiteradas crisis sociales y la incapacidad de disponer del control de recursos sociales por parte del Estado y sus continuos gobiernos. Bolivia desde siempre ha debido enfrentar la falta de cohesión social y extremas desigualdades sociales producto de su heterogeneidad cultural y regional. En efecto, "durante la segunda mitad del siglo XIX (...) el país se estremecía, por un lado, con los 
conflictos entre conservadores y liberales y, por otro, por la lucha regional debido al crecimiento de La Paz. Conocida como la guerra federal. Sumado a lo anterior la rebelión indígena, especialmente la de Zárate Willka (1899), contribuía a la inestabilidad interna (González, 2004:27). Pese a estas dificultades que han limitado la continuidad de su política exterior, producto de presiones sociales o respuestas voluntaristas, se pueden definir ciertas ideas clave que la inspiran y que alcanzan un amplio consenso en la elite boliviana. Dentro de éstas se destacan: "la reivindicación marítima, es decir, la necesidad de un acceso soberano al océano Pacífico, y el carácter central de su ubicación en Sudamérica, que la dispone a profundizar una política exterior abierta a la integración regional” (Zalles, 2007:37).

No obstante, la pérdida de su cualidad marítima supone un costo que se interpreta en el imaginario colectivo boliviano como una desmembración cualitativa, la guerra del Pacífico pasó a representar la guerra de las guerras y la cuna de la desconfianza hacia Chile (Francisco, 2009:47). La percepción sobre Chile ha sido una constante transversal y diacrónica. Aunque historiadores se preguntan si Bolivia tenía conciencia marítima en el siglo XIX. Pudiéndose "afirmar que la reivindicación boliviana de una cualidad perdida sería una construcción cultural del siglo XX o, mejor dicho, posterior al tratado de 1904.”(González, 2004:27), pues las elites mineras, liberales, bolivianas, privilegiaron acuerdos con Chile que mejoraran las exportaciones mineras, atendiendo las concesiones en materia comercial que les ofrecía el país vecino en vez de reivindicar una salida al mar. Para este mismo autor, "de lo que parece no haber discusión es que el mar ha sido un factor importante, como un ladrillo, en la conciencia nacional boliviana en su esfuerzo de construir un Estado-Nación”. Pero se trató de una empresa de inicios del siglo XX, al alero del proyecto de las Sociedad de las Naciones (1919) que promovía la solución de controversias entre estados a través de su mediación. Considerando además que la pérdida de su cualidad marítima se concibe generalizadamente como una de las causas fundamentales de su subdesarrollo económico y social; aunque pueda desmentirse, así lo entiende el pueblo boliviano y explica el resentimiento hacia Chile (Francisco, 2009). Sentimiento que oficialmente se recoge como un tema irrenunciable de su política exterior.

A pesar de que el reclamo marítimo y la apertura a Sudamérica han sido unas constantes en la política exterior boliviana, "está no ha tenido una tradición de continuidad institucional en su conducción y quienes la lideraron respondieron sobre todo a intereses políticos coyunturales” (Zalles, 2006:9) que responden más a presiones sociales (intelectuales, historiadores, Fuerzas Armadas, Etc.) que a una política de Estado.

\section{La década de 1950, la época dorada de las relaciones diplomáticas chileno bolivianas}

Pese a la persistencia de estos patrones entrado el siglo XX, la década de 1950 puede ser definida como la época dorada en las relaciones entre Bolivia y Chile. Se puede considerar un hito, toda vez que hubo un 
cambio de percepciones por parte de diversos sectores de la sociedad de ambos países hacia el otro.

1950 fue un punto de inflexión en las relaciones diplomáticas de Bolivia y Chile, ese año se realizaron las conocidas "Notas Reversales de $1^{\circ}$ y 20 de junio”, donde Chile manifestó que "animado de un espíritu de fraternal amistad hacia Bolivia, está llano a entrar, formalmente, en una negociación destinada a buscar la fórmula que pueda hacer posible dar a Bolivia una salida propia y soberana al Océano Pacífico, y a Chile obtener compensaciones que no tengan carácter territorial y que consulten efectivamente sus intereses” (Orias 2004:65).

En este acercamiento encontramos tanto variables desde nivel sistémico como desde el nivel de unidad que contribuyeron a comprender este hito clave en las relaciones chileno bolivianas: el desarrollo de una matriz estadocéntrica, desarrollista, inspiradora de un ideario integracionista. Elementos del régimen político propicios hacia un mayor acercamiento, como fue una sintonía entre las autoridades políticas y las respectivas sociedades en torno a un mayor acercamiento entre los dos países. El despliegue de una diplomacia comprometida con estos cambios con un estilo reconocible y la emergencia de proyectos de conectividad física internacional, entre otros.

El principal diario chileno, El Mercurio de Santiago, señalaba el $1^{\circ}$ de agosto de 1950 que se había informado al Senado sobre la cesión de un puerto a Bolivia. Trayendo una nota sobre la exposición del Canciller chileno ante la Cámara de Diputados. Al día siguiente, El Mercurio, incluye una opinión del Canciller Horacio Walker: "Chile no se ha negado a oír proposiciones de Bolivia en gestión directa”.

Ramiro Prudencio, en su recuento de hitos de negociaciones entre Bolivia y Chile durante el siglo veinte, identifica a estas notas entre el embajador boliviano en Chile, Alberto Ostria Gutiérrez y del canciller chileno, Horacio Walker Larraín ${ }^{8}$, como el segundo más importante después del Acta que se suscribió en La Paz, el 10 de enero de ese año, entre el Canciller Carlos Gutiérrez y el Ministro Plenipotenciario chileno, Emilio Bello Codesido, donde Chile se compromete en la búsqueda de una solución a la demanda marítima boliviana. Ese compromiso, empero, dependía de un posible triunfo chileno en el plebiscito por Tacna y Arica que involucraba a Perú (Prudencio, 232:2006).

Tanto en 1920 como en 1950 y en los hitos posteriores hasta nuestros días, el tema central de las negociaciones entre ambos estados ha sido la demanda marítima boliviana. Esta ha sido la piedra de toque o la piedra en el zapato de las relaciones bilaterales, según el caso. Ha sido el principal contenido de las percepciones donde la más contrapuesta ha sido el concepto de “usurpación” por parte de Bolivia y de “reivindicación” por parte de Chile.

Paz Estenssoro ganó las elecciones de mayo de 1951, del partido 
Movimiento Nacionalista Revolucionario (MNR), quien se sobrepuso a un Golpe de Estado, logrando el MNR gobernar el país hasta 1964, bajo el liderazgo de este mandatario y de Hernán Siles Suazo, su sucesor. Será bajo el periodo del MNR donde se realizarán los intentos más notables de integración física y cultural entre ambos países.

Una de las medidas más relevantes de la década de 1950 en Bolivia fue la creación de la COMIBOL (Corporación Minera de Bolivia) el 2 de agosto de 1952, dentro de una política de nacionalización de la minería. La idea fundamental no era ser "simplemente una heredera de los Barones del Estaño, sino un pivote indispensable para la independencia económica del país” (Torrez, 1986:21), donde se busco polos de desarrollo en Bolivia, entorno la nacionalización en medio de una revolución política liderada por el MNR, proyecto que miraba el pacífico, y por ende Chile como parte de su estrategia de inserción internacional. Percibiendo de manera positiva un posible acercamiento. Un elemento importante que destacamos en los aspectos teóricos apunta a que el régimen político boliviano tendría el control de un recurso clave para su estrategia hacia el exterior, obteniendo recursos desde la sociedad, adjudicándolos en orientación a sus preferencias (Merke, 2006). Proceso inédito en un país con gran peso de una elite minera de rasgos oligárquicos.

Otros los motivos para insistir en un intento de integración más sistemática entre ambos países lo encontramos en una de las fuerzas profundas de la política exterior chilena y sus consecuencias: la estabilidad institucional. Ésta le permitió desplegar una modernización fundada en el desarrollo infraestructural. Así, por ejemplo, la convicción con la cual construyó y promocionó la Carretera Panamericana redimensionó la significación de su frontera norte y su vinculación con los mercados de Perú y Bolivia. Bolivia, por su parte, enfrentó los cambios de régimen político generados por la revolución de 1952, que impactaron directamente en la expansión de sus mercados interno y externo (Zalles, 2007:41). Revitalizando nuevas rutas fronterizas en torno al comercio minero por el Norte de Chile.

En este marco, en enero 1955, surgiría otro hito en las relaciones diplomáticas entre los dos países, que daba cuenta del estilo pragmático y moderado de la diplomacia de ambos países, que por fin ponían la reivindicación marítima entere paréntesis: los presidentes Víctor Paz Estenssoro y Carlos Ibáñez del Campo firmaron un tratado de complementación económica, basado en el intercambio de petróleo boliviano por acero chileno, en el puerto de Arica ${ }^{9}$. El presidente Víctor Paz Estenssoro fue en visita oficial a Chile, y en agosto de ese año, el presidente Carlos Ibáñez del Campo hizo lo propio, visitando la ciudad de La Paz, un acontecimiento que se transformaría, como dijo el embajador Carlos Bustos: "la única visita oficial efectuada a ese país por un Presidente de Chile en casi dos siglos de historia republicana” (2004:184).

En cuanto al contexto internacional, el concepto "integración” comenzaba a pronunciarse cada vez con más fuerza, posiblemente como un 
aprendizaje de lo que había sido las dos guerras mundiales, lo que lleva a América Latina a plantearse sus propios acuerdo intrarregionales de integración económica. La década de 1950 coincide con el despliegue de la cuarta etapa de la integración latinoamericana, según la síntesis histórica expuesta por Gustavo lagos, que recoge Bernal -Meza: “es la época en que la corriente integracionista latinoamericana logra expresarse en una conciencia y en una estrategia de tipo económico que al principio se concibe en términos limitados, para alcanzar luego caracteres globales. Es en este periodo donde el pensamiento Cepalino comienza a cuajar en los primeros modelos (Bernal-Meza, 2005:48).

A su vez, en esta misma década se estaba forjando el destino de las ambiciosas propuestas integracionistas de las décadas siguientes, periodo que "se caracterizó por una conciencia y estrategia globales de la integración al nivel económico, político e intelectual. Esta etapa, (...) consigue dar sustento teórico-conceptual a una nueva dimensión, compleja y global, de la integración.” (Bernal-Meza, Raúl 2005:48) .Etapas en que Chile fue protagonista, en el plano práctico y de las ideas, a través del impulso doctrinario de figuras como Felipe Herrera, Hernán Santa Cruz y Gustavo Lagos.

En efecto, la década de 1950 fue la antesala de la "sensibilidad sesentista” (Devés, 2003:135) hacia la integración latinoamericana. Según Devés, Enrique Iglesias destacó que el concepto de cooperación con los países en desarrollo surge en el decenio de 1950, al influjo de de factores claramente políticos, entre los cuales pone de relieve la Guerra Fría y la descolonización” (2003:130).

Bajo este optimismo, América Latina configura una matriz política en que el Estado tanto en el plano doméstico como internacional será clave para promover un desarrollo en torno a una mayor integración continental, que no dejo ajeno Chile y Bolivia. Pues el agente del desarrollo en este continente no puede ser sino el Estado, "única estructura capaz de conducir la operación estratégica global del desarrollo” (Devés, 2003:144).

Como señala Bob Jessop, existen “escalas sobre las cuales ocurren intentos de de reestructurar relaciones económicas, políticas y sociales” y, “en los treinta años gloriosos de la expansión económica de postguerra, la escala nacional dominó la organización económica” (2004:26). Fue en esa escala donde se buscó una solución al problema económico en Bolivia. La solución, supuestamente, llegaría por la vía de una revolución desde arriba, con apoyo social. “La revolución de 1952, la nacionalización de las minas, la marcha al oriente, fueron entre otros eventos causales del inicio de un cambio en la orientación de la inserción internacional del país. En efecto, la transferencia de recursos de la minería y del petróleo junto con la incorporación de las tierras productivas del oriente y el desarrollo de la producción de alimentos agroindustriales, permitieron la sustitución de importaciones de alimentos tales como azúcar, arroz, aceite, etc. y, posteriormente, el desarrollo de exportaciones no tradicionales. También se ini- 
ció un nuevo ciclo de producción de hidrocarburos, con la participación de empresas extranjeras” (Seoane, 2008:66).

Este era el ambiente en que rodeaba las relaciones bilaterales entre Bolivia y Chile, donde la influencia de Estados Unidos, en el marco de la Guerra Fría se fue perfilando. En efecto, el presidente chileno Gabriel González Videla viajó a Estados Unidos a comienzos de 1950 a entrevistarse con el presidente Harry Truman, quien ofrece reunirse con los mandatarios de Bolivia y Chile para encontrar una solución a la demanda marítima boliviana.

El historiador y jurista chileno, Sergio Carrasco, señala que a partir de la visita del presidente chileno, Gabriel González Videla, a Washington, la diplomacia chilena cambia su posición frente a la demanda portuaria boliviana. Dice este autor: "Nunca hasta entonces, con la sola excepción de la aceptación de la sujeción Kellogg, el gobierno de La Moneda había reconocido la aspiración portuaria de Bolivia. Ahora lo hacía variando radicalmente la posición diplomática de Chile” (1991:244). Las conversaciones versaban sobre un posible corredor al norte de Arica que comunicara a Bolivia con la costa, mientras este país compensaría a Chile con aguas de los lagos Titicaca, Poopó y Coipasa.

\section{Las relaciones bilaterales en la prensa chilena en la década de 1950}

En Bolivia la visita del presidente chileno a Washington fue noticia destacada y levantó la expectativa que también visitara a La Paz. El diario El Tarapacá de Iquique, de 8 de febrero de 1950, titula: Bolivia espera visita del presidente Sr. González Videla

"El presidente de Bolivia Mamerto Urriolagoitía dijo que se hallaban muy adelantadas las gestiones para que el Presidente de Chile Gabriel González Videla visite Bolivia al regreso de su viaje de Estados Unidos, y que sería gratísimo para el sentimiento boliviano el viaje del eminente Presidente chileno".

Las relaciones de Chile y Bolivia con Estados Unidos, se realizaban en el marco de la Guerra Fría, por lo que este factor debía estar presente en los acercamientos de los tres países, en la medida que la percepción del otro se construía en base a imágenes como el anticomunismo, considerado una de las preocupaciones o expectativas clave de la elite política de ambos países.

Justamente, iniciado el año 1950 se encendían las luces de alarma ante la presencia comunista en Bolivia y Chile. El 6 de febrero el diario El Tarapacá de Iquique, exhibía la siguiente noticia:

"Complot comunista que tenía relación con huelgas en Chile se descubrió en Bolivia." La policía dijo que se trataba de un movimiento simultáneo con el de Chile. 
La Paz - La policía informó haber descubierto un complot que debía estallar mañana dirigido por el partido comunista recientemente formado en concomitancia con la huelga producida en Chile.

El comunicado agrega "Todo hace ver que el plan comunista que debía desarrollarse mañana tenía concomitancia estrecha con el plan que se desarrolla actualmente en Chile”.

En Bolivia, incluso se realizaron vigilancias en las escuelas para evitar que los comunistas pudieran alarmar a los escolares y sembrar el pánico. En Chile se había dictado la ley de defensa de la democracia, que declaraba al partido Comunista fuera de la legalidad, bajo el Gobierno de Gabriel González Videla.

Como hemos insistido, en la línea de de Der Derian que entiende la diplomacia como una forma de diálogo con el otro, que posibilita el acercamiento de culturas en tanto vehículo para el contacto entre comunidades humanas organizadas. (Der Derian, 1998:30). , en las decisiones de política exterior cobra relevancia la relación del Estado con la sociedad, preocupando el papel de las elites dirigentes y el nivel de autonomía que disponen frente a las presiones y demandas de la aquella. Por ello, podemos conjeturar que cuando las relaciones diplomáticas mejoran entre dos países vecinos, suelen reflejarse entre las sociedades civiles en la medida que las preferencias de ambos se encuentran. Desde este ámbito, actores no estatales inician acercamientos que, en algunos casos, podrían definirse de paradiplomáticos, generando ambientes más favorables para los actores diplomáticos. Veamos El Tarapacá de Iquique de 15 de febrero de 1950:

Entusiasta y triunfal recibimiento hizo Bolivia a futbolistas chilenos. Más de ocho mil personas con carteles de bienvenida llenaban la estación.

Ocho mil personas tributaron un cariñoso recibimiento a la delegación futbolística chilena. Carteles de bienvenida a los hermanos chilenos llenaban la estación. Los futbolistas chilenos debieron descender de los autos en que debían viajar desde el hotel a la estación, a pedido insistente del público que los potreaba. Los chilenos se concentraron en la localidad de Obrajes, a seis kilómetros de La Paz.

Este ambiente recibió las fiestas patrias de Bolivia en Santiago de Chile, posiblemente uno de los más celebrados y registrados por la prensa. Del día 3 de agosto, El Mercurio de Santiago, en su sección Crónica, describe los festejos por las festividades bolivianas que durarían hasta el día 11 de agosto. En los días siguientes vienen en la misma sección Crónicas, noticias sobre estas festividades. El mismo día patrio de Bolivia, en la segunda página, en la edición del domingo, se incluye un reportaje escrito por Alberto Ostria Gutiérrez, embajador boliviano en Chile, titulado: "Bolivia, corazón de la América del Sur”. El autor señala que la función de Bolivia en el panorama americano no es de conflicto, sino de encuentro y 
mediación. Finaliza el texto recalcando la importancia de la ubicación central de Bolivia como el corazón de América, que gracias a los ferrocarriles y a las labores políticas, posteriores a la Guerra del Chaco, ha podido cumplir su rol en el panorama continental. Mientras en la página 5 del mismo diario se hace referencia al aniversario de Bolivia, donde se hace mención del "avance y tranquilidad del país” y se le califica de "país amigo".

Al día siguiente de publicadas estas noticias sobre el aniversario de Bolivia, El Mercurio de Santiago, en su sección Exclusivos del exterior, informa: "Presidente Urriolagoitía ratifica anhelo de Bolivia de tener acceso al océano Pacífico". Incluyen el diario fragmentos del discurso del presidente boliviano del Congreso Nacional, efectuado el día 6, especialmente los relativos al corredor marítimo (El Mercurio 7 agosto 1950). Noticia que es ampliada el 8 de agosto, en la misma Sección: "Nueva declaración del Presidente Urriolagoitía sobre un puerto boliviano al Pacífico”. Haciendo referencias al apoyo de los presidentes Truman y Perón, y la comprensión que ha encontrado Bolivia en los presidentes chilenos Pedro Aguirre Cerda, Juan Antonio Ríos y Gabriel González Videla.

$\mathrm{Al}$ año siguiente, 1951, los diarios también se explayaron sobre el aniversario patrio boliviano. El Mercurio de Santiago, el mismo 6 de agosto, en la Portada, trae un nuevo ensayo de Alberto Ostria Gutiérrez, titulado "Bolivia”. Relato descriptivo en tono poético del altiplano, los llanos, el valle, La Paz, Potosí y Sucre. En el año 1952 se observa una mayor expresión de solidaridad. El Mercurio de Santiago de 7 de agosto, en la portada del Tercer Cuerpo, bajo el título: " $137^{\circ}$ aniversario de la Independencia de Bolivia se celebró en Santiago”, se incluye el discurso de Benjamín Aguirre Amenazar, presidente del Rotary Club de la capital chilena.

Además en 1952 era noticia la revolución del MNR en ese país, pues el 6 de agosto El Mercurio Santiago, en la Sección Informaciones Sudamericanas, informa:

"La Paz: En el discurso por motivo del aniversario patrio, del presidente Víctor Paz Estensoro dijo: la nacionalización de las minas y la reforma agraria, se han de cumplir inexorablemente en estos escasos meses de Gobierno de la Revolución Nacional”.

Otro elemento para comprender este mayor acercamiento surge si consideramos las ideas clave o visiones de mundo que estuvieran detrás de las respectivas políticas, sobre todo las distintas ideas que tienen los países acerca de lo que consideran relevante a la hora determinar la política exterior que promueven y que induzcan a determinados actos, asociados a la definición de su posición en el sistema internacional(Keohane, 2002:15) Así, la emergencia del panamericanismo latinoamericano, autonomista, de a mediados de siglo XX; las teorías dependentistas y su influencia en los modelos de desarrollo; la idea de inaugurar instituciones como la CEPAL, el BID, entre otros hitos, partirían de un cambio de matriz que tuvo repercusiones en la definición de las respectivas políticas exteriores. 
Para Bolivia y el Cono Sur de América Latina, El MNR representaba un cambio inédito. La revolución boliviana era, en muchos sentidos, un cambio estructural que Chile aún no estaba disponible para asumirlo, uno de esos cambios era la reforma agraria que, recién de la década siguiente, bajo el Gobierno de Jorge Alessandri, se inicia desde el Estado central a través de la ley 15.020 del año 1962. Sin embargo, ambos países comparten una fragilidad, junto a otros países latinoamericanos, como lo señala Antonio García: “En una peligrosa y elevada proporción, Chile depende el cobre, la Argentina de la carne y los cereales, Bolivia del estaño(...), revelando que este tipo arcaico de especialización internacional no es producto de una decisión interna sino una norma impuesta colonialmente desde afuera, desde la estructura misma del sistema capitalista mundial de relaciones de intercambio" (2006:205).

En agosto el presidente de Bolivia firmó el decreto sobre la reforma agraria donde se establece que "el suelo, el subsuelo y las aguas del territorio de la República pertenecen por derecho propio a la nación” (El Mercurio, Sección Exclusivos del Exterior, 3 agosto, p 26). El mismo diario trae la noticia en la Sección Exclusivos del Exterior, p. 19, del día siguiente que "Campesinos armados desfilaron en La Paz para celebrar la Ley de Reforma Agraria”. Se agregan datos de la prensa boliviana con relación a la reforma, y antecedentes del desfile en La Paz de los campesinos liderado por Alberto Mendoza. Sin embargo, se observa uno de los primeros problemas de este decreto: "Restitución de las tierras indígenas persigue reforma agraria boliviana” (El Mercurio, Sección Crónicas, 4 agosto).

Lo interesante de 1953, siguiendo las claves teóricas que propusimos, en tanto se aprecia una consonancia de intereses y percepciones entre actores estatales y no estatales de distintas partes del país, es que no sólo se destacan las celebraciones del aniversario de Bolivia en Santiago, sino también en Antofagasta y Chuquicamata (El Mercurio de Santiago, p. 27). En estas ciudades como en Iquique y Arica, existían Sociedades Bolivianas de Socorros Mutuos, plenamente vigentes.

Le correspondió al encargado de negocios de Bolivia en Santiago Luis Alberto Alipaz los alcances de la reforma agraria. Este diplomático también fue a quien se destacó en las celebraciones de ese año de las fiestas patrias de su país, en su discurso señaló: Esta, señores, es la síntesis de todas las vicisitudes del acontecer histórico de Bolivia, y es también la de todos nuestros pueblos de América, tan iguales en sus tradiciones, en su conformación sociológica y en su estilo. Pero hay en la oración una rotunda verdad que hoy, como pocas veces, tiene todos los signos de un hito en la época en que vivimos los bolivianos; y es la reafirmación del triunfo del pueblo. En Bolivia, ese pueblo ha vencido una vez más, pero esa cristalización de sus aspiraciones le ha costado mucho: ahí quedan miles de vidas truncadas en pleno florecimiento: ahí emergen las calles, las plazas y los campos como testigos mudos de tanto y tan heroico sacrificio. Y por éste, su desprendimiento valeroso, por este afán permanente de ser árbitro de su propio destino, ese pueblo merece para siempre la felicidad en su 
cotidiano batallar y en nombre de él, permítaseme señores rendir mi homenaje reverente al pueblo chileno, dueño de las más altas virtudes y de las más preciadas calidades cívicas, flor de éste pueblo, esencia de sus intimas inquietudes es la mujer chilena: para ella sean mis palabras de rendida admiración...(El Mercurio de Santiago, 6 de agosto, Portada, tercer cuerpo, p. 9)

El Mercurio de Santiago, 7 agosto 1953, (Sección Interior, p. 26) destaca las celebraciones del día de Bolivia en Tarapacá, en las ciudades de Arica e Iquique.

Durante al año 1954, se destaca la posible construcción del gran oleoducto desde Bolivia hacia Arica, el cual se construyó a partir de un Protocolo del Tratado de Complementación Económica, suscritos por el canciller boliviano Walter Guevara Arze y el embajador chileno en Bolivia, Alejandro Hales, suscrito en La Paz un 14 de octubre de 1955.

La noticia que traía El Mercurio de Santiago en la Portada del 4 de agosto fue la siguiente:

"Gigantesco oleoducto petrolero construirá Bolivia hasta Arica".

Arica: En avión especial del Lloyd Aéreo boliviano llegaron procedentes de La Paz, los señores José Paz Estensoro, hermano del primer mandatario de ese país y presidente de Yacimientos Petrolíferos Bolivianos; John Williams, presidente de la firma Williams Brothers; Eduardo Hinojosa, gerente de Yacimientos Petrolíferos Bolivianos y 6 ingenieros. EL grupo sobrevoló la ruta Camiri-Arica, para estudiar la posibilidad de construir a lo largo de ella un gigantesco oleoducto, destinado a facilitar la salida del petróleo boliviano hacia el extranjero.

El señor Paz expresó a El Mercurio su complacencia por ser apropiada la ruta escogida para la instalación del oleoducto. Añadió que su construcción se efectuará apenas el gobierno apruebe el proyecto, ya que ello representará, un gran impulso a la industria petrolera de Bolivia.

Este oleoducto refleja el estado de las relaciones entre ambos países y también del estado de ánimo de ambos pueblos, pues fue visto con gran expectativa a uno y otro lado de la frontera, a pesar de algunos reparos interpuesto por el Gobierno peruano en 1956 por su presidente José Luis Bustamante y Rivero, quien había sido embajador de su país en Bolivia ${ }^{10}$.

En 1955 la visita del presidente Carlos Ibáñez del Campo marco la agenda noticiosa. Todo giraba en torno a los acercamientos chileno-bolivianos. De esta forma publicaba El Mercurio de Santiago este acontecimiento doble: 3/agosto. En Portada:

"Nueva etapa en la política americana marca visita del presidente Ibáñez a La Paz. Complementación económica como base de las relaciones continentales - Declaraciones del embajador, Señor Fernando Iturralde” 
(...) Señaló que éste viaje servirá, para conocer las realidades económico-sociales del Altiplano, sólida base de las relaciones hemisféricas. Es, asimismo, digo, la segunda etapa de la reunión de Arica en la cual se echaron las bases de los futuros intercambios comerciales y a cuyo efecto, en el curso del mes próximo, llegará a Chile una comisión boliviana que se abocará al estudio detallado de los diversos rubros.

Consideró el diplomático, que los pormenores técnicos son sólo la continuación necesaria de los principios básicos que se estatuyeron en Arica, y que, seguramente se solidificarán en La Paz (...). Bolivia observó, se interesa por hierro redondo, artículos sanitarios, material de construcción, cobre elaborado, cemento y diversos otros ítems, y a su vez, puede abastecerse al mercado nacional.

(...)

El pueblo boliviano animado por éste espíritu y en plena etapa de transición, busca hoy, en el plano nacional, soluciones y realizaciones inmediatas.

"Bolivia condecorará a Ministros de comitiva del presidente Ibáñez"

El día 4 de agosto El Mercurio de Santiago en la sección Portada, segundo cuerpo, p. 21, destacaba la partida del presidente para reunirse con su homólogo boliviano Víctor Paz Estenssoro, decía el matutino: "Lo acompaña una comitiva de 20 personas integrada por ministros de estado, altos funcionarios de la administración pública, detalles de su despedida en Cerrillos, los honores dados por la fuerza aérea y detalles de su "residencia” en La Paz". siguiente:

La noticia llegada desde La Paz, en el día patrio de Bolivia fue la

El Presidente Carlos Ibáñez declarado huésped ilustre de la ciudad de La Paz" (con foto)

El mandatario chileno manifestó que su gobierno continuará la política de colaboración económica con Bolivia - Entrevista del presidente con Paz Estenssoro en el palacio de gobierno - Ovaciones de la multitud Saludo del cuerpo diplomático - Almuerzo campestre con brindis por el fortalecimiento de la amistad chileno-boliviana - Ceremonia solemne en la municipalidad - Discursos del alcalde de La Paz Señor Juan Luis Gutiérrez Grenier y del ministro de Obras Públicas de Chile Señor Alberto Schwerter - Celebración del día de la Independencia boliviana - Posible visita a Santa Cruz - Recepción en el Palacio Quemado.

(El Mercurio de Santiago, 6 de agosto, Sección Portada).

La visita presidencial generó una alta expectativa. Hubo un desfile de obreros y empleados en una cifra aproximada a los cien mil, todos armados de fusiles y ametralladoras, con carteles que decían "Gracias al pueblo de Chile y al General Ibáñez por el desbloqueo”. Hubo también una fiesta popular donde se bailó al ritmo de la música folklórica boliviana. "El presidente Ibáñez recibió en el Palacio de Gobierno a los jefes del MNR. Dirigentes obreros y nativos (sic)” (El Mercurio de Santiago, 7 de agosto, sección Portada, tercer cuerpo, p. 27). 
Mientras el presidente Ibáñez abordaba el problema de la salida al mar para Bolivia, señalando que era un problema de carácter continental, diciendo inclusive que "a Bolivia debería dársele una salida también por el Atlántico”, el presidente de Paz Estenssoro anunciaba elecciones presidenciales para el próximo año. (El Mercurio de Santiago, 8 de agosto, sección Portada, segundo cuerpo, p.19). Al día siguiente el presidente de Bolivia partía con rumbo a Ecuador y Colombia, mientras el presidente chileno lo hacía en dirección a Santa Cruz de la Sierra.

Efectivamente hubo elecciones al año siguiente, 1956, saliendo electo Hernán Siles Suazo. Chile envió una delegación una comitiva para asistir a la transmisión del mando. Siles asumió la presidencia el mismo 6 de agosto de 1956. Las elecciones se realizaron el 17 de junio y tuvo por novedad que fueron las primeras donde las mujeres y los anafalbetos pudieron votar. Además, el Congreso boliviano volvió a entrar en funciones después de seis años de inactividad.

El año 1957 comenzó a mostrar los primeros quiebres de la revolución boliviana. El vicepresidente Ñuflo Chávez renunció a su cargo por diferencias con el presidente Siles, para después retirar esa renuncia generando un conflicto mayor con el primer mandatario.

El Mercurio de Santiago, en su sección Exclusivos del exterior, p. 29, publicaba la siguiente nota: "En un telegrama enviado ayer al Congreso, hizo conocer su determinación de seguir en el cargo al cual había dimitido por desacuerdo con Hernán Siles Zuazo. Mientras tanto, Juan Lechín fue reemplazado como presidente del Senado, por Federico Álvarez Plata”. Esto significaba que ya no se contaba con el apoyo irrestricto de los mineros bolivianos como había sido hasta entonces. Además los estudiantes secundarios seguían con sus movilizaciones iniciadas el año anterior por la muerte del condiscípulo Elio Augusto Crispieri en manos de desconocidos. En este hito visualizamos que Bolivia pierde un elemento clave para consolidar su política exterior hacia Chile: la falta de cohesión interna para afrontar un proyecto de cambio de envergadura el torno a la revolución de 1952.

Ese era el ambiente en Bolivia iniciado el año 1958, que podría calificarse de euforia y crispación, generado por una revolución que había levantado muchas expectativas, incluyendo la solución al tema marítimo con Chile.

\section{Conclusiones}

La imagen la entendemos como apariencia y semejanza de un episodio que convierte la realidad en una abstracción que permite su interpretación por parte del ser humano (Rodao, 2005). Para nuestro caso la imagen que tenían los estadistas y actores regionales de ambos países hacia este acercamiento inédito. A su vez, la percepción surge cuando estos esta- 
distas y sus sociedades les conceden un significado intrínseco a esa imagen (Rodao, 2005; Schumacher, 2002.). Surgidas de procesos cognitivos como la giras presidenciales, mitines, celebraciones patrias y comitivas descritas por la prensa, y al amparo de motivaciones o expectativas futuras, como era una solución a la mediterraneidad, junto con la implementación de medidas de integración física entre ambos países, estas nuevas imágenes que proyectaron Chile y Bolivia los acercaron a un entendimiento inédito y a buscar intereses complementarios como nunca en su larga historia de conflictos.

Como hemos insistido, las percepciones están relacionadas a imágenes, las que se confunden con la realidad objetiva. Schumacher se pregunta: “¿Entonces, si no es en la realidad objetiva en la que basamos nuestros juicios y decisiones, en qué es? Obviamente en nuestra realidad objetiva, pero que es solamente una imagen, es la realidad objetiva tal como se ha proyectado dentro de nuestras mentes, es la realidad objetiva tal como la vemos nosotros” (2002:79). Lo relevante es que las naciones de ambos países, y sus autoridades políticas coincidieron en la mirada: la primera vio en el interior de continente grandes oportunidades económicas, posiblemente sobre la base de su memoria histórica del ciclo de la plata, (Sampa 1972); y la segunda, vio en el océano Pacífico su apertura al mundo, al mercado internacional para sus productos mineros y agropecuarios. Esa coincidencia de miradas también se expresó en imágenes coincidentes, donde las expectativas eran crecientes en la medida que las autoridades respondían a sus demandas y el clima diplomático era favorable.

Por otro lado, podríamos conjeturar, siguiendo la variable régimen político, que profundizan tanto el realismo neoclásico como al teoría de las percepciones, que Chile estuvo más cerca que nunca de alcanzar un acuerdo con Bolivia en la década de 1950 respecto a una salida al mar producto de que ambos poseían un mayor control sobre los recursos económicos y sociales al pasar de un modelo liberal oligárquico a un modelo de desarrollo hacia adentro, y la presencia de valores y creencias, en tanto imágenes, coincidentes, en las elites políticas de ambos países acerca de los asuntos mundiales ( en torno a la idea de una integración sistemática del continente), y cómo ellos se relacionan con los intereses externos e internos del Estado (Lasagna,1996).

Fue, posiblemente, 1950 una década donde se podría afirmar con Deustch (1990), que ambos Estado-naciones lograron "una consonancia cognitiva” que les permitió aproximarse, aunque posiblemente no suficiente como para comprender los códigos tácitos, superar las imágenes distorsionadas y el sistema de creencias construidos respecto del otro.

Complementando esta afirmación, las teorías internacionales realistas neoclásicas (Rose, 1998; Zakaria, 2000), plantean que un elemento clave para comprender la incidencia de las percepciones en las conductas de los tomadores de decisiones pasa por la relación del Estado con la sociedad y su incidencia en las decisiones de política exterior. Para esta corriente, 
que nos aporta pistas para comprender este fracasado proyecto de integración, no siempre la sociedad está a disposición de los líderes y por lo tanto los dirigentes expandirán los intereses políticos de la nación en el exterior cuando perciban un aumento relativo del poder estatal. (Zakaria 2000: 50). En definitiva, conjeturamos que la demanda por una mayor integración física, fue un desafío que no logro permear las percepciones de los diplomáticos tradicionales; si bien hubo una época dorada de las relaciones diplomáticas entre ambos países en la década de 1950, la integración física era vista como una práctica que debilitaba el poder nacional y no era parte de sus motivaciones en la medida que la percepción del otro se construía en base a imágenes como el centralismo, -imagen histórica construida por ambos Estado-naciones- considerado una de las preocupaciones o expectativas clave de la elites políticas de ambos países.

Finalmente, nos cabe destacar desde una mirada actual que las imágenes construidas por las regiones hacia estos acercamientos no siempre coincidían con las imágenes construidas desde los respectivos centro políticos y sus agentes diplomáticos. Sea en la actualidad o en 1958, estamos frente a un fenómeno donde notoriamente existe una irrupción de la sociedad civil con referencia internacional, pues aunque sean regiones contiguas, por ejemplo lo acontecido entre Tarapacá y Oruro, lo son de dos países distintos y con relaciones diplomáticas complejas. Esa relación internacional, podría suponerse que potenciaría regiones cercanas al proponer sus demandas dentro de una agenda bilateral. De tal modo, esta fuerza regional-internacional debería transformarse en un contrapoder del poder central de los dos Estado-naciones de Bolivia y Chile. Supuestamente, el escenario que enfrentarían los movimientos regionales de 1958 sería más difícil debido al poder que los Estado-naciones tenían en dicha época, comparado en el periodo actual de globalización, donde las fronteras permiten más fácilmente la emergencia de proyectos internacionales concebidos desde las regiones. 


\title{
Notas
}

\section{${ }^{1}$ Artículo resultado del proyecto FONDECYT regular 1095130 y del proyecto Ecos-Conicyt $\mathrm{C} 08 \mathrm{H} 02$}

${ }^{2}$ Vgr. La importancia de la Dirección General de Relaciones Económicas Internacionales, DIRECON, dentro de las distintas unidades de la cancillería.

\begin{abstract}
${ }^{3}$ Respecto a dotar de nuevo contenido a la idea de interés nacional, podemos mencionar la aportación del constructivismo al concepto. Esta corriente plantea salir de denominaciones inmóviles, así, los conceptos dejan de ser realidades materiales para convertirse en construcciones sociales. Para los constructivistas, el interés nacional es el resultado de ideas compartidas, identidad nacional y prácticas normativas. Lejos por tanto de ser un concepto estático, los intereses nacionales de los estados se forman dentro de un contexto cultural como resultado de la interacción social”. (Herrero, 2010.21)Es decir, el interés nacional surge de la socialización y el aprendizaje mutuo, por tanto supone un "concepto intersubjetivo del proceso en el que las identidades y los intereses son endógenos a la interacción, en lugar de ser exógenos y dados, como apunta el concepto racionalista representado por las variantes realistas”. (Hopf 1998: 199).
\end{abstract}

${ }^{4}$ Esta rígida división ontológica es impugnada por el realismo neoclásico cuyo aporte teórico radica, además de combinar variables internacionales y domesticas para intentar comprender la acción externa de un Estado, en la incorporación de variables ajenas a la tradición realista, en términos ontológicos. (...) Para el realismo neoclásico, tanto los recursos materiales (propia de la ontología del paradigma positivista) como las percepciones del mundo subjetivo inciden a la hora de comprender la vinculación externa de un Estado (Actis,2011)

${ }^{5}$ Críticas a la imposibilidad de un actor racional en política internacional y sus premisas (que son actores egoístas, maximizadores de beneficios, que el individuo precede a la sociedad, entre otros postulados) la encontramos en Herrero de Castro (2006:68,69 y ss.), quien a su vez sigue a Mary Zay (1992).

${ }^{6}$ Podríamos conjeturar que Chile estuvo más cerca que nunca de alcanzar un acuerdo con Bolivia respecto a una salida al mar producto del mayor control sobre los recursos económicos y sociales al pasar aun modelo de desarrollo hacia adentro y la presencia de valores y creencias coincidentes respecto a la mirada internacional.

${ }^{7}$ Lasagna (1996:32) en su propuesta de análisis, profundiza en los atributos del régimen político potencialmente alterables, que incidan en la política exterior, sobre todo e presencia de un cambio de régimen: "Comenzaremos por las relaciones Estado-sociedad, y la manera en que éstas influyen en la posibilidad de cambio de la política exterior. Utilizaremos dos indicadores para medir el impacto del cambio de régimen en las relaciones Estadosociedad: el grado de autonomía del Estado respecto a la opinión pública y las élites sociales; y el grado de control sobre los recursos de política exterior.” Complementa su análisis con las variables principios y valores que están en la base del régimen y guían a los líderes en cuanto a sus preferencias respecto a los asuntos mundiales.

${ }^{8}$ Oscar Pinochet de la Barra, resalta la personalidad de estos diplomáticos en el acercamiento entre Bolivia y Chile en 1950 (1987:68) 
${ }^{9}$ Ya en 1954, se podía leer en El Mercurio de Santiago del 4 de agosto, Sección Portada: "Gigantesco oleoducto petrolero construirá Bolivia hasta Arica"

Arica: En avión especial del Lloyd Aéreo boliviano llegaron procedentes de La Paz, los señores José Paz Estensoro, hermano del primer mandatario de ese país y presidente de Yacimientos Petrolíferos Bolivianos; John Williams, presidente de la firma Williams Brothers; Eduardo Hinojosa, gerente de Yacimientos Petrolíferos Bolivianos y 6 ingenieros. El grupo sobrevoló la ruta Camiri-Arica, para estudiar la posibilidad de construir a lo largo de ella un gigantesco oleoducto, destinado a facilitar la salida del petróleo boliviano hacia el extranjero. El señor Paz expresó a El Mercurio su complacencia por ser apropiada la ruta escogida para la instalación del oleoducto. Añadió que su construcción se efectuará apenas el gobierno apruebe el proyecto, ya que ello representará, un gran impulso a la industria petrolera de Bolivia”. Nemesio Araya, corresponsal.

${ }^{10}$ Puede ser inevitable la comparación con la cerrada oposición que hubo respecto del intento de los Gobiernos de Bolivia y Chile, de los presidentes Jorge Quiroga y Ricardo Lagos, respectivamente, por construir un gasoducto que uniera Bolivia con un puerto chileno del Pacífico. 


\section{Bibliografía}

Actis, Esteban (2011), Hacia una comprensión del comportamiento externo de Brasil bajo la administración Lula. Aportes del Realismo Neoclásico. Mundorama. Divulgação científica em Relações Internacionais - ISSN 2175-2052

Arnoletto, Eduardo (2007), Curso de Teoría Política, Edición. Eumed.net. Disponible en : www.eumed.net/libros/2007b/300/

Atkins. Pope (1991), América Latina en el Sistema Político Internacional, Grupo editorial latinoamericano, Buenos Aires.

Barbé, Ester (2003), Relaciones Internacionales, Editorial Tecnos, Segunda Edición, Madrid

Bernal-Meza, Raúl (2005), América Latina en el mundo. El pensamiento latinoamericano y la teoría de las relaciones internacionales, Nuevohacer, Grupo editorial latinoamericano, Buenos Aires.

Bizzozero, Lincoln (2009), La sociedad uruguaya y la percepción de Brasil: el ingreso del tiempo histórico en la construcción del regionalismo. Consejo Uruguayo para las Relaciones Internacionales, Estudio No 02/09.

Bustos, Carlos (2004), Chile y Bolivia. Un largo camino. De la independencia a Monterrey, RIL Editores, Santiago.

Carrasco, Sergio (1991), Historia de las relaciones chileno-bolivianas, Editorial Universitaria, Santiago.

Colacrai, Miryam y Lorenzini, María Elena (2005), «La política exterior de Chile: ¿excepcionalidad o continuidad? Una lectura combinada de fuerzas profundas y tendencias». Confines, Vol. 1 N². pp. 45-63.

Der Derian, James (1998), “Teoría y tradición en las relaciones internacionales tardías”. En Carlo Nasi, Posmodernismo y Relaciones Internacionales, Universidad Javeriana, Bogotá.

Der Derian, Jean (1987), On Diplomacy: A Genealogy of Western Estrangement. Oxford, Blackwell.

Deutsch, Karl (1990), El análisis de las Relaciones Internacionales, Ediciones Guernica, México

Devés, Eduardo (2000), Del Ariel de Rodó a la Cepal (1900-1950). El pensamiento latinoamericano en el siglo XX. Entre la modernización y la identidad. Tomo I, Editorial Biblos, Centro de Investigaciones Barros Arana, Santiago. 
Ídem (2003), El pensamiento latinoamericano en el siglo XX. Desde la Cepal al neoliberalismo (1950-1990). Tomo II, Editorial Biblos, Centro de Investigaciones Barros Arana, Santiago.

Fermandois Joaquín (2004), Mundo y fin de mundo: Chile en la política mundial 1900-2004, Ediciones Universidad Católica de Chile, Santiago.

Fernandois, Joaquín y León Hulaud, Michelle (2005), “¿Antonimia entre democracia y gobierno militar? Chile y Argentina en el momento de incertidumbre (1955 -1973)". En Pablo Lacoste (editor), 2005. Argentina, Chile y sus Vecinos, Tomo II, Caviar Bleu, Mendoza-Argentina, pp. 93-141.

Francisco, Mila. (2009), “La cuestión Marítima en la política exterior de Chile y Bolivia.” Revista Diplomacia No 118, enero - marzo ,pp.47-69

Garretón, Antonio Manuel (2002), “La transformación de la acción colectiva en América Latina”. Revista de la Cepal, No 76, abril, pp.7-24.

González Miranda, Sergio (2004), “La tercería boliviana y el problema de la Mediterraneidad”. Revista Fuerzas Armadas y Sociedad, Año 18(1-2), pp. 23-36.

Herrero de Castro, Rubén (2010), El concepto interés nacional. En: evolución del concepto interés nacional. Centro superior de estudios de la defensa nacional, Madrid.

Ídem (2006), "La realidad inventada. Percepciones y proceso de toma de decisiones en política exterior”, Plaza Valdés editores, Madrid.

Hopf, Ted (1998), "The promise of constructivism in International Relationstheory”. International Security, 23 (1), pp. 171-200.

Jervis, Robert (1976), Perception and Misperception in International Politics. Princeton, Princeton University Pres

Jessop, Bob (2004), “La economía política de la escala y la construcción de las regiones transfronterizas”. EURE. vol.30, Nº.89:90.

Keohane, Robert (2002), "Las ideas, tan solo una parte de la explicación.” Revista Desafíos $N^{\circ}$ 6, Semestre I. Foro "Social Theory of International Politics” El pensamiento de Alexander Wendt. Universidad del Rosario, Bogota, Colombia.

Lasagna, Marcelo (1996), “Cambio institucional y política exterior: un modelo explicativo”, en Revista. CIDOB d' Afers Internacionals, $N^{\circ} 32$, pp.45-64 
Lawson George (2006), “La imaginación sociológica desde la perspectiva histórica” Revista Académica de Relaciones Internacionales, N 5 Noviembre, UAM-AEDRI ISSN 1699 395. Disponible en: www. relacionesinternacionales.info [citado 2011 -03-05]

Merke, Federico. (s/f) “Identidad y Política Exterior en la Teoría de las Relaciones internacionales”. IDICSO, Instituto de Investigación en Ciencias Sociales Facultad de Ciencias Sociales Universidad del Salvador, Argentina.

Montobbio Manuel (2004), “La cultura y los nuevos espacios multilaterales” Pensar Iberoamérica, Revista de Cultura. $N^{0} 7$, septiembre - diciembre. Organización de Estados Iberoamericanos para la Educación, la Ciencia y la Cultura.

Morgenthau, Hans (1986), Política entre las naciones. La lucha por el poder $y$

La paz, Grupo Editor Latinoamericano, Buenos Aires.

Muñoz, Heraldo (1986), Las relaciones exteriores del gobierno militar chileno, PROSPEL-CERC. N, Santiago.

Nohlen, Dieter y Fernández, Mario. (1991), “Democratización y Política Exterior: Análisis comparado en torno a tres casos: Argentina, Brasil y Uruguay”, Revista Estudios Internacionales N94, pp. 229-259.

Orias, Ramiro (2004), “Bolivia-Chile: La cuestión de la mediterraneidad. Algunas consideraciones desde el derecho internacional”. Revista Fuerzas Armadas y Sociedad, Año 18, N 1-2, pp. 51-73.

Pinochet de la Barra, Oscar (1987), ¿Puerto para Bolivia? Centenaria negociación, Ed. Salesiana, Santiago.

Prudencio, Ramiro (2006), "La cuestión marítima boliviana en la actualidad”. Revista Universum, vol.21, Nº1, pp.231-239.

Renouvin, Pierre \& Durosselle, Jean-Baptiste (2000), Introducción a la Historia de las Relaciones Internacionales, Fondo de Cultura Económica, México.

Rodao, Florentino (2005), “Imágenes y proceso de toma de decisiones”.En Terceras Jornadas. Imagen, cultura y tecnología (Amador Carretero, Pilar, Jesús Robledano Arillo y Rosario Ruiz Franco, eds. Madrid, Universidad Carlos III, pp. 215-222.

Rose, Gideon (1998), “Neoclasical Realism and Theories of Foreign Policies”, World Politics, 51(1), pp. 144-172.

Rubio García, Leandro (1971), “historia, derecho y relaciones internacio- 
nales” Revista de Política Internacional N ${ }^{\mathrm{a}}$ 118. Noviembre - Diciembre, pp. 105-122

Russell, Roberto (1992), Enfoques teóricos y metodológicos para el estudio de la política exterior, (Ed). Programa de Estudios Conjuntos sobre las Relaciones Internacionales de América Latina, Argentina.

Russell Roberto y Juan Gabriel Tokatlian (2001), “Relaciones internacionales y política interna: Los neutrales en la Segunda Guerra Mundial, un estudio de caso”, Foro Internacional, Vol. XLI, N. 1, Enero-Marzo.

Salomón, Mónica (2002), “La Teoría de las Relaciones Internacionales en Los Albores del Siglo XXI: Diálogo, Disidencia, Aproximaciones”. Revista Electrónica de Estudios Internacionales. N ${ }^{\mathrm{a}}$ 4/.AEPDIRI. España. Disponible en: www.reei.org. [citado 2011 -05-05]

Sempat, Carlos (1972), “Integración y desintegración regional en el espacio colonial”. Revista EURE, No 4, marzo, CIDU-IPU, PUC, Santiago.

Seoane, Alfredo (2008), “La inserción de Bolivia en la economía mundial. Una mirada crítica al post-neoliberalismo”. Revista Umbrales, № 17 , pp. 5792.

Schumacher, Mark (2002), "La percepción en la historia y en las relaciones internacionales de la época moderna” Revista Pedralbes, N22, pp. 73-110.

Tomassini, Luciano (1989), Teoría y práctica de la política internacional, Ediciones Universidad Católica de Chile, Santiago.

Torrez, J.G. (1986), Minería e integración boliviana. Editorial Juventud, La Paz.

Waltz, Keneth (1979), Theory of International Politics, New York, McGrawHill.

Witker, Iván (2000), “Política exterior vecinal de Chile en los 90: ¿realismo sub-regional o nuevas oscilaciones del péndulo?” Si Somos Americanos Vol. III N², pp. 199 - 213

Wilhelmy, M. (1979), "Hacia un análisis de la Política Exterior chilena contemporánea”, Estudios Internacionales, Nº48, pp. 440-471

Zalles, Alberto (2007), "Bolivia y Chile: los imperativos de una nueva época”. Nueva Sociedad No 207, pp. 34-44,

Zakaria, Fareed (2000), De la Riqueza al Poder. Los Orígenes del Liderazgo Mundial de Estados Unidos, GEDISA, Barcelona. 
Polis, Revista de la Universidad Bolivariana, Volumen 11, $N^{\circ}$ 32, 2012

Zey, Mary (1992), “Criticisms of Rational Choice Models.” In Decision Making: Alternatives to Rational Choice Models, SAGE,

Recibido: 08.03.2012

Aceptado: 11.07.2012 